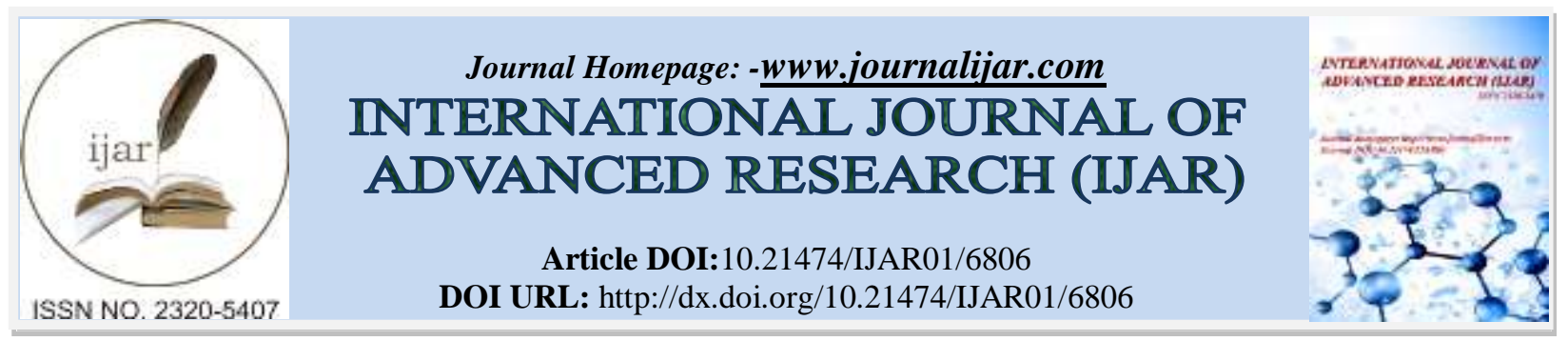

RESEARCH ARTICLE

\title{
A CRITIQUE ON CANCER VACCINE.
}

\section{Sambathkumar $\mathbf{R}^{1}$, Amala Baby ${ }^{2}$, Sudha $\mathbf{M}^{3}$ and Venkateswaramurthy $\mathbf{N}^{2}$.}

1. Department of Pharmaceutics.

2. Department of Pharmacy Practice.

3. Department of Pharmacology J.K.K. Nattraja College of Pharmacy, Kumarapalayam, Tamilnadu - 638183, India.

\section{Manuscript Info}

Manuscript History

Received: 21 January 2018

Final Accepted: 23 February 2018

Published: March 2018

Keywords:-

Cancer vaccine, Cells, Treatment.

\section{Abstract}

The goal of a successful vaccine is to prepare the immune system for invasion of a foreign pathogen and teach them to recognize antigens as well as reduce the risk of transmission. In the field of cancer, vaccines are found to be the latest discovery. Provenge ${ }^{\circledR}$ (Sipuleucel-T) is the only vaccine approved by Food and Drug Administration for the treatment of cancer. Vaccines are an appealing therapeutic strategy because they are specific. In addition they stimulate the adaptive immune system, thereby producing a memory response allowing for sustained effect without repeated therapy. Revelation of a potential anticancer treatment is as yet a test to the researchers. Thus, the development of effective cancer vaccines require, thoughtful clinical trials, and scientific progress which might induce long-term specific anticancer response and could contribute to effective and lasting elimination of malignant cells.

Copy Right, IJAR, 2018,. All rights reserved.

\section{Introduction:-}

Worldwide 6.7 million deaths were reported due to cancer in 2000 . But the WHO has predicted this figure to be 15 million by 2020. ${ }^{[1,2]}$ Despite great efforts to develop better therapy, in 1997 more than 6 million people worldwide died from cancer. Techniques that are being used currently for cancer treatment are Laser Therapy, Photodynamic Therapy \& Stem Cell Therapy. ${ }^{[3,4]}$

The term cancer vaccine refers to a vaccine that counteracts contaminations with cancer causing viruses and treats existing cancer or keeps the enhancement of disease in certain high hazard people. ${ }^{[5]}$

\section{Therapeutic vaccines:-}

Therapeutic vaccines have two goals: priming Ag-specific $\mathrm{T}$ cells and reprogramming memory $\mathrm{T}$ cells. When a cancer-causing virus infects its target cell, it often expresses viral specific antigens. As a result of expressing nonself antigens, virus induced prophylactic treatments are the natural first anti-cancer therapy. There are four infectious agents that cause ninety percent of pathogen induced cancers: Hepatitis B Virus (HBV),Human Papilloma Virus (HPV), Hepatitis C Virus (HCV), and Helicobacter pylori. ${ }^{[6]}$ But only vaccines for Hepatitis B Virus and human papilloma virus are available. 
Cancer vaccines are entering a renaissance period because of an arrangement of clinical trial that yielded empowering clinical results. To begin with, therapy of metastatic prostate cancer with sipuleucel-T (APC8015), a cellular vaccine in light of advanced blood Antigen Presenting Cells (APCs) which is quickly refined with a combination protein of prostatic acid phosphatase with granulocyte-macrophage colony stimulating factor (GMCSF). ${ }^{[7]}$ Sipuleucel-T has been endorsed by the FDA for therapy of prostate metastatic tumor, in this manner clearing the clinical advancement and administrative way for the upcoming era of cell immunotherapy materials.

Sipuleucel-T is created through the in vitro stimulation of the patient's own peripheral blood mononuclear cells obtained by leukapheresis. ${ }^{[8]}$ Secondly, a stage III trial in metastatic melanoma testing peptide vaccine in mix with high dosage Interleukin-2 (IL-2) versus Interleukin-2 alone demonstrated huge change in generally speaking reaction rate and movement free survival in patients who received vaccine. ${ }^{[9]}$ Third, a stage III trial in patients with follicular lymphoma demonstrated that idiotype vaccine therapy (BiovaxID) fundamentally draws out the span of chemotherapy-induced remission. ${ }^{[10]}$

Moreover, a randomized phase II trial of a vaccine based on pox virus focusing on prostate particularly $\mathrm{Ag}$ (PROSTVAC) in men with metastatic castration resistant prostate disease demonstrated an improved general survival in patients accepting control vectors. ${ }^{[11-16]}$

PROSTVAC is consists of a series of poxviral vectors that are capable to express prostate-specific antigen (PSA). ${ }^{[17]}$ The vaccine is designed to break immunologic tolerance to prostate-specific antigen. ${ }^{[18]}$ The vaccine for human papilloma virus is Merck's Gardasil®. It was approved by FDA in 2006. It protects against infection from four strains of human papilloma virus. ${ }^{[19]}$ Gardasil ${ }^{\circledR}$ helps protect girls and young women ages 9 to 26 against two types of HPV that cause about $75 \%$ of cervical cancer cases and two more types that cause $90 \%$ of genital wart cases. In 2009 the FDA approved Gardasil ${ }^{\circledR}$ for use in boys and men, for the prophylaxis of genital warts caused by human papilloma virus. So Gardasilß is the only HPV vaccine approved for use in males and females. In 2009 worldwide sales of Gardasil $₫$ was $\$ 1.1$ billion. ${ }^{[20]}$ GlaxoSmithKline's Cervarix ${ }^{\circledR}$ is the second vaccine for human papilloma virus, which is used for the prevention of cervical pre-cancers, FDA approved Cervarix ${ }^{\circledR}$ on October 16, 2009. ${ }^{[21]}$

PANVAC is a recombinant poxviral vaccine that includes transgenes for the Tumor associated antigens(TAAs), MUC-1 and Carcinoembryonic antigen (CEA). MUC-1 is a transmembrane glycoprotein that is overexposed in under glycosylated form in carcinoma cells of humans. ${ }^{[22,23]}$ Carcinoembryonic antigen is another glycoprotein overexpressed on the most of adenocarcinomas. Its selective overexpression additionally creates it a potential focus for immunotherapy. ${ }^{[24,25]}$

The first vaccination with recombinant vaccinia (PANVAC-V) limited its continuous use due to the production of host induced neutralizing antibodies. Subsequent vaccination with recombinant fowlpox (PANVAC-F), however does not stimulate neutralizing antibody production because fowlpox is replication deficient in humans and can't produce late viral proteins. ${ }^{[26]}$ Granulocyte-macrophage colony-stimulating factor(GM-CSF) is also given as a vaccine adjunct to enhance the migration and maturation of Antigen presenting cells. ${ }^{[6,27]}$

Currently there are several techniques to treat cancer, Bone Marrow Transplants, Chemo Therapy, Gene Therapy, Radio Therapy \&Stem Cell Therapy. ${ }^{[3]}$

\section{Targeting tumor antigens:-}

Antigen-specific vaccines:-

The ideal breast cancer vaccine would induce broadly reactive immunity to different sorts of breast cancer without creating clinically significant autoimmunity and be clinically effective. In addition to MUC-1, HER2/neu, and

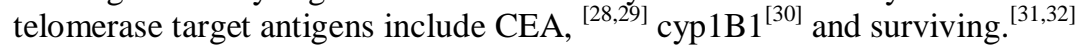

MUC-1-In cancer patients Overexpression and aberrant glycosylation of mucin-1 (MUC-1) antigen results in endogenous antibody responses to MUC-1antigen. ${ }^{[33]}$

HER2/neu-The HER2/neu antigen is a popular target of antibody-mediated immunotherapy in breast cancer. hTERT-The catalytic subunit of telomerase, hTERT is a widely expressed tumor antigen, present in more than $85 \%$ of all human cancers. ${ }^{[34]}$ 


\section{Types of cancer vaccines:-}

According to cancerous cell growth:-

Prophylactic vaccines: which prevents cancer from developing in healthy people; andTherapeutic vaccines: which used to treat an existing cancer by strengthening the body's natural defense. ${ }^{35]}$

According to conventional allopathic medicine, types of cancers can be categorized as carcinomas, sarcomas, leukemias, lymphomas and myelomas. ${ }^{[36,37]}$

According to the treatment:-

Specific Cancer Vaccines - Used to treat specific type of cancers.

Universal Cancer Vaccines - Used to fight cancer cells regardless of its type. ${ }^{[38]}$

\section{Different kinds of cancer vaccines:-}

1. Antigen vaccines

2. Tumor cell vaccines

3. Anti-Idiotype antibody-based vaccines

4. Dendritic cell vaccines

5. DNA vaccines

6. Viral-vector based vaccines

\section{Antigen vaccines:-}

Antigen vaccines stimulate the immune system by using tumor specific antigens. These are usually proteins or peptides. By injecting these antigens into the cancerous area of the patient, the immune system will produce an increased amount of antibodies known as killer $\mathrm{T}$ cells/ $\mathrm{T}$ lymphocytes that carry specific antigen to attack cancer cells. Antigen vaccines are using only one antigen to boost the immune system. ${ }^{[39]}$

Tumor immunotherapy can be classified as (a) passive (or adaptive) and (b) active, represented by vaccines, aimed at eliciting a particular immune reaction against tumor specific antigens (TSAs) and tumor-associated antigens (TAAs). Both have their specificities and restrictions. ${ }^{[40,41]}$

\section{Tumor cell vaccines:-}

Tumor cell vaccines are made up of actual cancer cells which have been removed during surgery. Doctors also change the cells, often by adding chemicals or new genes, to make them more likely to be seen as foreign by the immune system. Then the cells are injected into the individual (patient). The immune system recognizes antigens on these cells and then it attacks any other cells with these antigens that are still in the body.

In some cases, doctors give the vaccine alongside substances called adjuvants that increase the immune response. A possible advantage of tumor cell vaccines over antigen-based vaccine is that not all cancer antigens have been found yet.

Details about some of the cancer cells and cell fragments that are used in tumor cell vaccines:

Tumor oncolysates: an extract made from cancer cells contaminated with a strain of virus.

Transduced tumor cells: cancer cells that have been altered to incorporate genetic material from cytokines, proteins that empower the activity of immune cells, including cytotoxic T cells. ${ }^{[42]}$

Currently whole tumor cell vaccines are being developed to treat threatening cancers such as Acute Myeloid Leukemia (AML). ${ }^{[43]}$

Anti-idiotype antibody-based vaccines:-

Immunoglobulin (Ig) molecules contain highly specific, unique peptide sequences at the antigen-combining sites. These can be recognized as idiotypes by forming the unique antigen recognition site of the Immunoglobulin protein. ${ }^{[44]}$ 


\section{Dendritic cell vaccines:-}

Dendritic cells are the most effective antigen presenting cells. Dendritic cells help the immune system to recognize cancer cells. The cancer cells break down into smaller pieces and then hold out these antigens to T cells. This makes it easier for the immune system to recognize and attack them.

\section{DNA vaccines:-}

DNA vaccines are active in mammalian cells. DNA vaccines have many favorable circumstances for tumor antigens. To start with, some extent; encoded antigens can enter the processing and presentation pathways of the immune system and induce innate and adaptive immune responses. Second, non-specific innate immunity stimulation is given by the bacterial DNA. ${ }^{[45-49]}$

Major advantages are:

1. Ease of production.

2. Cheaply \& conveniently produced \& purified.

3. Do not require special handling or storage conditions.

4. They elicit immune responses only to the encoded antigens.

5. Plasmid DNA-based products are safe and there are now several products in late-testing. ${ }^{[50]}$

\section{Viral-vector based vaccines:-}

These vaccines use vectors to make them more effective. Vectors are special viruses, bacteria or other structures that can be used to get antigens or DNA into the body. The vectors are frequently microbes that have been altered to ensure they can never again cause disease.

Advantages of using vectors:

1. They can deliver more than one cancer antigen at once, which make the body's immune system more likely to mount a response.

2. They mimic a natural infection, and in this way it gives the necessary "danger signals" required for optimal activation of antigen presenting cells.

3. They are easier and more affordable to make than some other vaccines. The first viral vector used was vaccinia, a poxvirus, more than 20 years back. ${ }^{[51]}$ From that vaccine, a few different vectors have been created in light of the poxviruses, such as the Modified Vaccinia virus Ankara (MVA) ${ }^{[52]}$ which is a non replicating vaccinia virus and avian poxviruses, such as fowlpox ${ }^{[53]}$ and canarypox. ${ }^{[54]}$

\section{Side effects of cancer vaccines:-}

The most commonly reported side effect of cancer vaccine is inflammation at the site of injection, including warming of the skin, swelling and occasionally a rash. After receiving a cancer vaccine, people sometimes experience flu like symptoms including fever, chills, dizziness, fatigue, headache and occasional breathing difficulties.

When compared with traditional vaccines, these types of vaccines intended to treat cancer seem to have safety profiles. ${ }^{[55]}$ However, the side effects of cancer vaccines can vary among vaccine formulations and from one individual to another. More serious health problems like asthma, appendicitis, pelvic inflammatory disease and certain autoimmune diseases have been reported in smaller number of people.

Table 1:-Table for cancer vaccine ${ }^{[56-58]}$

\begin{tabular}{|l|l|l|}
\hline Company & Product & Indication \\
\hline Avax Technologies & M-Vax & Metastatic melanoma \\
\hline Dendreon & Provenge & $\begin{array}{l}\text { metastatic hormone refractory prostate } \\
\text { cancer }\end{array}$ \\
\hline Geron & GRNVAC1 & $\begin{array}{l}\text { AML Acute myeloid leukemia) in } \\
\text { remission }\end{array}$ \\
\hline \multirow{2}{*}{ IDM Pharma } & $\begin{array}{l}\text { Superficial bladder } \\
\text { Cancer }\end{array}$ \\
\cline { 2 - 3 } & Uvidem & $\begin{array}{l}\text { stage III and } \\
\text { IV melanoma }\end{array}$ \\
\cline { 2 - 3 } & Collidem & Colorectal cancer \\
\hline
\end{tabular}




\begin{tabular}{|l|l|l|}
\hline $\begin{array}{l}\text { Introgen } \\
\text { Therapeutic }\end{array}$ & INGN 225 & $\begin{array}{l}\text { Advanced metastatic } \\
\text { SCLC (small cell lung cancer) } \\
\text { Breast }\end{array}$ \\
\hline MolMe & M3TK & Metastatic melanoma \\
\hline $\begin{array}{l}\text { Northwest } \\
\text { Biotherapeutics }\end{array}$ & DC-Vax Prostate & $\begin{array}{l}\text { Hormone-dependent, } \\
\text { Non metastatic } \\
\text { prostate cancer }\end{array}$ \\
\hline & $\begin{array}{l}\text { Radiation } \\
\text { and chemotherapy }\end{array}$ \\
\hline Prima Biomed & $\begin{array}{l}\text { Late-stage ovarian } \\
\text { Cancer }\end{array}$ \\
\hline
\end{tabular}

\begin{tabular}{|l|l|l|}
\hline Company & Product & Indication \\
\hline Cell Genesys & $\begin{array}{l}\text { GVAX } \\
\text { pancreatic }\end{array}$ & $\begin{array}{l}\text { Metastatic pancreatic } \\
\text { Cancer }\end{array}$ \\
\hline Pharmexa & GV1001 & $\begin{array}{l}\text { Pancreatic } \\
\text { Liver } \\
\text { Lung }\end{array}$ \\
\hline Onyvax & Onyvax-P & $\begin{array}{l}\text { Hormone-resistant } \\
\text { prostate cancer }\end{array}$ \\
\hline Antigenics & $\begin{array}{l}\text { HSPPC-96 } \\
\text { Oncophage }\end{array}$ & Recurrent glioma \\
\cline { 2 - 3 } & & $\begin{array}{l}\text { Resected renal-cell } \\
\text { carcinoma (RCC) }\end{array}$ \\
\hline $\begin{array}{l}\text { Biovest } \\
\text { International }\end{array}$ & BiovaxID & Non-Hodgkin's lymphoma \\
\hline Apthera & NeuVax & $\begin{array}{l}\text { Early-stage Her-2- } \\
\text { positive breast cancer }\end{array}$ \\
\hline CellDex & CDX-110 & $\begin{array}{l}\text { Glioblastoma } \\
\text { Multiforme }\end{array}$ \\
\hline $\begin{array}{l}\text { Cytos } \\
\text { Biotechnology }\end{array}$ & $\begin{array}{l}\text { Advanced-stage } \\
\text { Melanoma }\end{array}$ \\
\hline GenerexBiotechnology & $\begin{array}{l}\text { CYT004- } \\
\text { MelQbG10 }\end{array}$ & $\begin{array}{l}\text { Node-negative breast } \\
\text { Cancer }\end{array}$ \\
\hline $\begin{array}{l}\text { Immatics } \\
\text { Biotechnologies }\end{array}$ & $\begin{array}{l}\text { Renal Cancer Colorectal } \\
\text { Cancer }\end{array}$ \\
\hline $\begin{array}{l}\text { Norwood } \\
\text { Immunology }\end{array}$ & $\begin{array}{l}\text { Melanoma } \\
\text { cancer vaccine }\end{array}$ & $\begin{array}{l}\text { IMA901IMA910 } \\
\text { cancer vaccine }\end{array}$ \\
\hline
\end{tabular}

\section{Conclusion:-}

Cancer has become one of the most disastrous diseases around the world. Possibly, discovery of a Universal Cancer Vaccine will be the most exciting attainment of this century. The ultimate goal of vaccine-based cancer immunotherapy is to elicit a potent immune response that will cause the eradication of the tumor. Despite great efforts for better treatments, more than 6 million people worldwide died from cancer. Worldwide, the vaccine development for Cancer is an exemplary approach of researchers to fight the most dreadful disease.

Continued efforts, clinical trials and scientific progress will permit the advancement of more strong focus on treatments for cancer patients. Given the abundance of concepts originating from the research centers, the next decade presages unprecedented growth in the development of effective cancer vaccines. 


\section{References:-}

1. IARC, World cancer report, (WHO). 2003.

2. Rastogi T, Hildesheim A, Sinha R. Opportunities for cancer epidemiology in developing countries. Nat Rev Cancer. 2004;4(11):909-917.

3. Jaganti V, Sukirti DT, Sai S. A review on cancer vaccines.Int J Pharma Bio Sci. 2011;2(3):86-97.

4. Cancer - The role of genes, lifestyle \& environment by Joseph Panno, PhD.

5. Claudia N. Bibliotheca Alexandrina 120433. Available from: http://www.bibalex.org/libraries/presentation/static/Cancer_Vaccines_eng_1204.pdf.

6. Itoh K. Jpn J Clin Oncol. 2009;39:73-80.

7. Kantoff PW, Higano CS, Shore ND, Berger ER, Small EJ, Penson DF et al. Impact study investigators. SipuleucelT immunotherapy for castration-resistant prostate cancer. N Engl J Med. 2010;363(5):411-422.

8. Madan RA, Gulley JI, Fojo T, Dahut WI. Therapeutic cancer vaccines in prostate cancer: The paradox of improved survival without changes in time to progression. Oncologist. 2010;15(9):969-975.

9. Schwartzentruber DJ, Lawson D, Richards J, Conry RM, Miller D, Triesman J et al. A phase III multi institutional randomized study of immunization with the gp100:209-217 (210M) peptide followed by high-dose IL-2 compared with high-dose IL-2 alone in patient with metastatic melanoma. J Clin Oncol. 2009;27:18.

10. Schuster SJ, Neelapu SS, Gause BL, Muggia FM, Gockerman JP, Sotomayor EM et al. Idiotype vaccine therapy (BiovaxID) in follicular lymphoma in first complete remission: phase III clinical trial results. J Clin Oncol. 2009;27(suppl; abstr2):18s.

11. Kantoff PW, Schuetz TJ, Blumenstein BA, Glode LM, Bilhartz DL, Wyand M et al. Overall survival analysis of a phase II randomized controlled trial of a pox-viral based PSA-targeted immunotherapy metastatic castrationresistant prostate cancer. J Clin Oncol. 2010;28(7):1099-1105.

12. Gulley J, Chen AP, Dahut W, Arlen PM, Bastian A, Steinberg SM et al. Phase I study of a vaccine using recombinant vaccinia virus expressing PSA (rV-PSA) in patients with metastatic androgen-independent prostate cancer. Prostate. 2002;53(2):109-17.

13. Sanda MG, Smith DC, Charles LG, Hwang C, Pienta KJ, Schlom J et al. Recombinant vaccinia-PSA(PROSTVAC) can induce a prostate-specific immune response in androgen-modulated human prostate cancer. Urology. 1999;53(2):260-266.

14. Eder JP, Kantoff PW, Roper K, Xu GX, Bubley GJ, Boyden J et al. 2000. A phase I trial of a recombinant vaccinia virus expressing prostate specific antigen in advanced prostate cancer. Clin Cancer Res. 2000;6(5):1632-1638.

15. Arlen PM, Skarupa L, Pazdur M, Seetharam M, Tsang KY, Grosenbach DW et al. Clinical safety of a viral vector based prostate cancer vaccinestrategy. J Urol. 2007;178(4 pt 1):1515-1520.

16. Dipaola RS, Plante M, Kaufman H, Petrylak DP, Israeli R, Lattime E et al. A phase I trial of pox PSA vaccines (PROSTVAC-VF) with B7-1,ICAM-1, and LFA-3 co-stimulatory molecules (TRICOM) in patients with prostate cancer. J Transl Med. 2006;4:1.

17. Madan RA, Arlen PM, Mohebtash M, Hodge JW, Gulley JL. Prostvac-VF: a vector-based vaccine targeting PSA in prostate cancer. Expert Opin Investig Drugs. 2009;18(7):1001-1011.

18. Gulley JL, Madan RA, Tsang KY, Jochems C, Mart JL, Farsaci B et al. Immune impact induced by PROSTVAC (PSA-TRICOM), therapeutic vaccine for prostate cancer. Cancer Immunol Res. 2014;2(2):133-141.

19. Gardasil® prescribing information (www.gardasil.com.)

20. Merck \& Co, Inc. form 10-K as filed with the securities and exchange commission on march $1 ; 2010$.

21. GlaxoSmithKline plc form 20-F as filed with the securities and exchange commission on march 1; 2010.

22. Karsten U, Mensdorff-Pouilly SV, Goletz S. What makes MUC1 a tumor antigen. Tumor Biol. 2005;26:217-220.

23. Duraisamy S, Kufe T, Ramasamy S, Kufe D. Evolution of the human MUC1 oncoprotein. Int J Oncol. 2007;31(3):671-677.

24. Benchimol S, Fuks A, Jothy S, Beauchemin N, Shirota K, Stanners CP. Carcinoembryonic antigen, a human tumor marker, functions as an intercellular adhesion molecule. Cell. 1989;57(2):327-334.

25. Marshall J. Carcinoembryonic antigen-based vaccines. Semin Oncol. 2003;30(3 supp 8):30-36.

26. Marshall JL, Hoyer RJ, Toomey MA, Faraguna K, Chang P, Richmond E et al. Phase I study in advanced cancer patients of a diversified prime-and-boost vaccination protocol using recombinant vaccinia virus and recombinant non replicating avian pox virus to elicit anticarcinoembryonic antigen immune responses. $J$ Clin Oncol. 2000;18(23):3964-3973.

27. Kass E, Panicali DL, Mazzara G, Schlom J, Greiner JW. Granulocyte/macrophage-colony stimulating factor produced by recombinant avian pox viruses enriches the regional lymph nodes with antigen-presenting cells and acts as an immune adjuvant. Cancer Res. 2001;61(1):206-214.

28. Morse MA, Clay TM, Hobeika AC. Phase I study of immunization with dendritic cells modified with fowlpox encoding carcinoembryonic antigen and costimulatory molecules. Clin Cancer Res. 2005;11(8):3017-3024.

29. Morse MA, Nair SK, Mosca PJ. Immunotherapy with autologous, human dendritic cells transfected with carcinoembryonic antigen mRNA. Cancer Invest. 2003;21(3):341-349. 
30. Brossart P, Wirths S, Stuhler G. Induction of cytotoxic T-lymphocyte responses in vivo after vaccinations with peptide-pulsed dendritic cells. Blood. 2000;96(9):3102-3108.

31. Wobser M, Keikavoussi P, Kunzmann V. Complete remission of liver metastasis of pancreatic cancer under vaccination with a HLA-A2 restricted peptide derived from the universal tumor antigen survivin. Cancer Immunol Immunother. 2006;55(10):1294-1298.

32. Otto K, Andersen MH, Eggert A. Lack of toxicity of therapy-induced T cell responses against the universal tumor antigen survivin. Vaccine. 2005;23(7):884-889.

33. Taylor-Papadimitriou J, Finn OJ. Biology, biochemistry and immunology of carcinoma associated mucins. Immunol Today. 1997; 18:105-107.

34. Vonderheide RH, Hahn WC, Schultze JL. The telomerase catalytic subunit is a widelyexpressed tumor-associated antigen recognized by cytotoxic T lymphocytes. Immunity. 1999;10(6):673-679.

35. Lollini PL, Cavallo F, Nanni P, Forni G. Vaccines for tumor prevention. Nat Rev Cancer. 2006;6(3):204-216.

36. Michael L. Beating cancer with natural medicine. Library of congress control. 2003;56.

37. Matthias R. Cellular health series: cancer, first edition, MR publishing, inc. 2001;50-52.

38. Kumar P, Prasanthi S, Lakshmi VRS, Saisantosh MV. Cancer vaccines: A promising role in cancer therapy. AJCR. 2010;3:16-21.

39. Graziano DF, Finn OJ. Tumor antigens and tumor antigen discovery. Cancer Treat Res. 2005;123:89-111.

40. Bendle GM, Holler A, Downs AM, Xue SA, Stauss HJ. Broadly expressed tumor associated proteins as targets for cytotoxic T lymphocyte-based cancer immunotherapy. Expert Opin Biol Ther. 2005;5(9):1183-1192.

41. Schietinger A, Philip M, Schreiber H. Specificity in cancer immunotherapy. Semin immunol. 2008;20(5):276-285.

42. Treatment immunotherapy: tumor cell vaccines. Melanoma centre. Available from:http://www.melanomacenter.org/treatment/tumorcellvaccines.html.

43. Cheuk AT, Guinn BA. Immunotherapy of acute myeloid leukaemia: development of a whole cell vaccine. Front Biosci. 2008;13:2022-2029.

44. Stevenson GT, Stevenson FK. Antibody to a molecularly-defined antigen confined to a tumor cell surface. Nature. 1975;254:714-716.

45. Timmerman JM, Czerwinski DK, Davis TA. Idiotype-pulsed dendritic cell vaccination for B-cell lymphoma: clinical and immune responses in 35 patients. Blood. 2002;99(5):1517-1526.

46. Maecker HT, Umetsu DT, DeKruyff RH, Levy S. Cytotoxic T cell responses to DNA vaccination: dependence on antigen presentation via class II MHC. Immunol.1998;161(12):6532-6536.

47. Chan K, Lee DJ, Schubert A, Tanq CM, Crain B, Schoenberger SP et al. The roles of MHC class II, CD40, and B7 costimulation in CTL induction by plasmid DNA. J Immunol. 2001;166(5):3061-3066.

48. Pfaar O, Cazan D, Klimek L, Larenas-Linnemann D, Calderon MA. Adjuvants for immunotherapy. Curr Opin Allergy Clin Immunol. 2012;12(6):648-657.

49. Victoria AP, Rachael LM, Barbara G, Ian S, Judith MR, Lindy GD. DNA vaccination with T-cell epitopes encoded within molecules induces high-avidity anti-tumor CD81 T cells. EurJ Immunol. 2010;40(3):899-910.

50. Schalk JA, Mooi FR, Berbers GA, Vanaerts LA, Ovelgonne H, Kimman TG. Preclinical and clinical safety studies on DNA vaccines. Hum Vaccine. 2006;2(2):45-53.

51. Mackett M, Smith GL, Moss B. Vaccinia virus: a selectable eukaryotic cloning and expression vector. Proc Natl Aca Sci USA. 1982;79(23):7415-7419.

52. Drexler I, Staib C, Sutter G. Modified vaccinia virus ankara as antigen delivery system: how can we best use its potential. Curr Opin Biotechnol. 2004;15(6):506-512.

53. Souza AP, Haut L, Reyes-Sandoval A, Pinto AR. Recombinant viruses as vaccines against viral diseases. Braz $J$ Med Biol Res. 2005;38(4):509-522.

54. Debruyn G, Rossini AJ, Chiu YL. Safety profile of recombinant canary pox HIV vaccines. Vaccine. 2004;22(56):704-713.

55. Burger. Ludwig. Update 2-Merck to test stimuvax cancer drug in Phase III. 2009.

56. Luigi B, Annacarmen P, Maria LT, Franco MB. Translating tumor antigens into cancer vaccines. Clin Vaccine Immunol. 2011;18(1):23-34.

57. Bruce G, Laura D. The cancer vaccine roller coaster. Nat Biotechnol. 2009;27(2):129-139.

58. Kuyler D, Shelly B, Philip V. The ongoing hopes and challenges of cancer oncology business review. 2010. 